\title{
Combustion and Society: A Fire-Centred History of Energy Use
}

\author{
Nigel Clark and Kathryn Yusoff
}

Theory, Culture \& Society

Special Issue: Energy \& Society

2014, Vol. 31(5) 203-226

DOI: $10.1177 / 0263276414536929$

\begin{abstract}
Fire is a force that links everyday human activities to some of the most powerful energetic movements of the Earth. Drawing together the energy-centred social theory of Georges Bataille, the fire-centred environmental history of Stephen Pyne, and the work of a number of 'pyrotechnology' scholars, the paper proposes that the generalized study of combustion is a key to contextualizing human energetic practices within a broader 'economy' of terrestrial and cosmic energy flows. We examine the relatively recent turn towards fossil-fuelled 'internal combustion' in the light of a much longer human history of 'broadcast' burning of vegetation and of artisanal pyrotechnologies - the use of heat to transform diverse materials. A combustioncentred analysis, it is argued, brings human collective life into closer contact with the geochemical and geologic conditions of earthly existence, while also pointing to the significance of explorative, experimental and even playful dispositions towards energy and matter.
\end{abstract}

\section{Keywords}

Anthropocene, Bataille, energy, fire, fossil fuels, pyrotechnology

\section{Introduction}

By way of NASA's collating of satellite images into quick time animations, it is now possible to get an impression of all the significant fires that have blazed across the Earth's surface over the last thirteen years. These are depicted in a colour scale which 
ranges from red indicating one fire a day in a thousand square kilometre area through to white indicating as many as a 100 fires (NASA, 2013 unpag). Viewed month by month, the animation shows swathes of pixelated flame - representing a complex mix of lightning-sparked wildfire and controlled agricultural burning - pulsing across the planet's major landmasses in distinct and repetitive seasonal rhythms.

In addition to the open flames licking across the planet's vegetative cover, a typical terrestrial day is punctuated by some 400 trillion tiny explosions. These explosions are the result of a spark igniting a small amount of compressed fuel and air, each one pushing a cylinder up or down within a metallic casing - and in this way propelling vehicles from one place to another. As the NASA Earth Observatory website puts it: 'On Earth something is always burning' (2013, unpag). But a great deal of this combustion, such as the reactions that propel the planet's billion plus automotive fleet, is now sequestered far from sight.

Combustion is the reaction in which chemical energy is converted into thermal energy. As such, it is one amongst a numerous possible conversions of the various energies - electromagnetic, chemical, thermal, kinetic, electrical, nuclear and gravitational (Smil, 2006: 10). Energy - usually understood as a `capacity for doing work' - is a rather abstract and compendious notion. It is important to recall, however, that work is not simply mechanical exertion or application of force, but anything that induces a change in the state of an affected system (Smil, 2006: 8-9). Combustion, then, is a particular form of 'work' in which energy held in the atomic bonds of a fuel is released through oxidation - a reaction with oxygen or an oxygen-rich compound - 
resulting in the release of heat and the formation of new chemical bonds. 'Fire' is the common term for rapid or chain reaction combustion.

Terrestrial fire and biological life have a shared chemistry: fire feeds off and decomposes the energy-rich carbon compounds assembled by the solar-powered process of photosynthesis (Pyne, 1994; 2004: 21). Today, most of the energy used by human beings, outside of their own bodily energetic reactions, comes from the combustion of fossilised organic matter that was originally powered - directly or indirectly - by photosynthesis. The impact of mass consumption of fossil fuels on the atmospheric composition and ecology of the Earth is now at the forefront of claims that cumulative human agency may have ushered in a new geological epoch. It is noteworthy that the notion of the Anthropocene is being championed by atmospheric chemist Paul Crutzen (2002), whose earlier research drew attention to the role of anthropogenic fire in global change. As Crutzen announced two decades ago in a text which set out to integrate the fields of wildland fire science and atmospheric chemistry: 'the preservation and study of fire will assist humanity in its larger stewardship of the Earth' (Goldammer and Crutzen, 1993: 11).

In this paper we are interested in what it might mean for our understanding of human energy use, and of social life more generally, to put combustion at the centre of our analysis. But as with other approaches to 'the energy question', thinking through combustion quickly draws us beyond the human, beyond life, and even beyond the Earth. While the Anthropocene thesis suggests that the issue of human energy use is tied up with a certain humanisation of geology, we propose that a deep temporal and wide-ranging focus on combustion points to another option, a kind of geologisation of 
the human (see Yusoff, 2013). Such a move, however, is not without precedent in social thought.

As Georges Bataille (1991: 10) observed half a century ago, 'the movement of energy on the earth' binds human social existence to the rest of the living world, it connects biological life to the planet as a whole, and in turn implicates our planet in the inhuman reaches of the solar system (see Stoekl, 2007: xiv -xvi, Clark, 2011: 126130). Drawing on geochemist Vladimir Vernadsky's (1998) pioneering depiction of solar-powered biosphere, Bataille offered a vision of earthly life as embroiled in a dynamic interplay between the limited space of spherical planet and the effectively limitless excitations of solar energy (1991: 29). Just as it is an imperative for biological life in general, how to expend a superabundance of energy is a challenge for every human society. Jettisoning economic modernity's self-understanding as a ceaseless struggle with scarcity, Bataille insisted that all societies grapple with the problem of what to do when they generate a surplus. With its institutionalization of a positive feedback loop of reinvestment and growth, he argued, industrial capitalism is an extreme case. At its heart is a ceaseless productive build-up with no safety valve; ,an energetic material amassing that has already 'turned the whole world into a colossal powder keg' (1993: 428).

We take the exigencies of the current energetic and environmental predicament as a prompt to 'substantiate' some of the more speculative Bataillean themes. In particular, the consequences of the spiralling combustion of fossil fuels invite a more literal reading of the frequent figurations of fire in Bataille's work. If not to reach an explosive pressure, accumulated wealth, he wrote, must be 'immolated', consumed in 
‘conflagrations' or 'incandescence'. Likewise, for environmental historian and fire scholar Stephen Pyne (1994, 1997a) the idea that organic matter can endlessly pile up in forests, scrubland or savannah without ever being 'expended' in an occasional outburst of fire is a modern myth. The consequence is an ever greater amassing of flammable phytomass, which will eventually discharge itself in wildfire - the longer the wait the fiercer the inferno. Just as deadly, Pyne proposes, is the idea that fossilfuelled combustion can replace the fires that periodically sweep through vegetated landscapes.

Bataille's energy-centred geophysics and, more directly, Pyne's pyrocentric global ecology draw attention to those human communities who know how to send biotic bullion up in a blaze of glory. In a broader sense, they prompt us to look at all the multifarious practices through which combustion is incorporated in, and animates social life. But both theorists also encourage us to the track flows and outbursts of energy far beyond their 'capture' in particular social forms or orders. More recently, political theorist Timothy Mitchell has suggested that in order to make any sense of the current energy predicament, we need to `follow the carbon itself' (2011: 6, 2010: 400). The pursuit of the elemental underpinnings of the contemporary `socialenergetic metabolism' takes Mitchell through pipes and tanks and distillation towers, down into deposits of carbon locked in the lithosphere, and back to the carbonplumped ecosystems of 150-300 million of years ago (2011:12-13). And finally, echoing Pyne, Bataille, Vernadsky—not to mention Nietszche — it draws him out beyond the confines our own small planet to the exuberant solar source of terrestrial heat and light. 
Following fire itself, we too set out to explore social-energetic metabolisms: tracking flows, congealings and irruptions that soon exceed the bounds of conventional social scientific analysis - and begin to stretch even the more recent affirmations of the heterogeneous composition of society. The generalised study of combustion-we suggest — is a key to contextualising human energetic practices within a broader 'economy' of terrestrial and cosmic energy flows (Bataille referred to this as a "general" rather than a "restricted" economy). The fire that burns beneath the cooking pot is much the same fire that rages through a forest, and has raged through foliage for hundreds of millions of years. Fire, in other words is a force that binds intimate and mundane human activities to some of the most 'monstrous' energetic movements of the Earth. As Gaston Bachelard puts it, fire '...links the small to the great, the hearth to the volcano, the life of a log to the life of a world' (1964: 16).

We set out by considering the definitive properties of terrestrial fire, and move on to address the peculiar occlusion of fire in western thought. After examining the role of contained combustion in the contemporary fossil-fuelled energetic regime, we turn to the long human history of open-air burning: the ancient and widespread use of fire as a means of unleashing the energies stored in vegetal matter. In between the polarities of broadcast burning and 'internal' combustion, however, there is another set of firewielding practices that should not be overlooked. Spanning some 10,000 years of human history — co-constitutive with the development and spread of agriculture — is a time of experimental and increasingly expert use of heat to transform the structure of inorganic matter. Heeding the counsel of pyrotechnology scholar Theodore Wertime, we touch base with `the often forgotten but massive effects of man's re-shaping of earthy materials by fire' (1983: 446) 
Through an unabashedly combustion-centred analysis, we aim to bring human collective life into closer contact with the geochemical and geologic conditions of earthly existence. As is the case with all energetic reactions, there are properties, dynamics and thresholds of combustion that are physically constant—and, hence socially non-negotiable. In crucial ways, we suggest, the characteristics and contours of terrestrial combustion subtend social life. But in a paradox that Bataille's logic of gratuitous expenditure announces and affirms, the effect of energetic invariance is anything but a determination. It is, rather, a subtending and a provoking of inestimable possibility.

What the history of human fire-use brings into view is the profusion and diversity of collective practices through which human communities have elaborated on basal elemental conditions. More specifically, a focus on combustion draws us into processes of material transmutation and metamorphosis that are more encompassing than the mechanical or kinetic forces that still tend to be the main object of social scientific analyses of energy. In this way, we begin to see that not only do so many social deployments of fire seem exceed determination, they often appear to overflow any discernible sense of direction, purpose or utility. Far from nailing social life to the dictates of necessity, then, fire histories hint intriguingly that human beings may be at their most experimental, playful and flamboyant precisely when they are riffing off the 'givens' of geology and geochemistry (see Bachelard, 1987: 15-16). Or as Maurice Blanchot (1995) put it, 'The Work of Fire' in its simplest form is the part of fire in the division of the whole — which is the part of play. 


\section{Ontologies of Combustion}

Whatever residual associations of fire with playful experimentation may have smouldered on in the cultures of modernity, rising apprehension around climate change appears to be imposing a stark new calculus and a grim symbolism on freeranging fire. Whereas 'immolation' in Bataille's corpus referred to the glorious fate of all stockpiled matter-energy — a deferrable but ultimately unavoidable release from circuits of value and accountability - fire is increasingly being viewed as environmental externality that must be internalised. In a context in which rising atmospheric carbon dioxide levels are understood to be the main driver of climate change, there is a growing imperative to account for all activities that add significant quantities of carbon to the global mix. The burning of a wooded land, in this light, appears doubly destructive: at once an immediate carbon dioxide emission and the loss of a future carbon sink (Pyne, 1997a: 539-43).

Recent scientific studies of the impact of fire on global climate have been working towards a more discriminating approach to the different modalities of burning biomass (see Bowman et al 2011; Marlon et al, 2009). But beyond this specialist field, there remains a strong tendency to conflate all forms of combustion-cyclical biomass burn-offs, permanent forest destruction, and the mass consumption of fossilised hydrocarbons - into single register of destructive carbon emissions. More than a matter of suboptimal carbon stock management, any verdant landscape in flames provides a spectacle of climatic catastrophe in the making: offering the kind of visual drama which complex climate models or the latest figures on biodiversity loss deny to a non-specialist audience (see Pyne, 1997a: 541). 
However, while a critical reassessment of the benefits of combusting fossilised hydrocarbons is no more than a few decades old, it is important to recognise that the condemnation of open fire has been gathering force for several centuries. This turn against the burning of living biomass is arguably one of the most momentous — and, one of the strangest-behavioural inversions our species has ever undertaken. As Pyne likes to remind us, the genus Homo are the only species on Earth which have routinely manipulated fire (1994: 889). Some evolutionary anthropologists have suggested that — both culturally and biologically_-learning to handle fire is the single most important moment in becoming human. While some estimates extend the ability of hominin species to control fire as far back as 1.6 million years before the present, clear stratigraphic evidence of the ash remains of in situ fire use has been dated to approximately 1 million years ago (Berna et al, 2012).

More than a turning point in human evolution, Pyne proposes, 'the capture of fire by Homo marks a divide in the natural history of the Earth' (1994: 889). The fact that fire was there to be appropriated, he argues, reflects the uniqueness of our planet. It is the presence of life - specifically life-forms capable of converting the electromagnetic energy of solar radiation into chemical energy stored in tissue - that makes combustion such a significant and definitive mode of energy conversion on our planet. The essential ingredients of rapid combustion are fuel, free oxygen and a means of ignition, each of which, as Pyne points out, are found elsewhere in the solar system (1997b: 3). Saturn's moon Titan has fuel (in the form of methane), Mars has oxygen traces, Jupiter has lightning. But only our planet has all three components in a workable assemblage. 
Marine phytoplankton first produced the oxygen as a by-product of photosynthesis, the vascular plants which colonised the Earth's landmasses during the Devonian period supply the carbon fuels, while lightning and volcanism provide the ignition (Pyne, 1997a: 16-17). In all its many variations, this basic arrangement held for around 400 million years. Then, at some point in the lower Pleistocene, hominin species learned to capture and propagate fire. When 'a uniquely fire creature became bonded to a uniquely fire planet' Pyne intones, the very dynamics of terrestrial combustion began to shift (1994: 889).

If fire-use made the species that we became "jump" into a new evolutionary path, this trajectory eventually took fire-carrying hominin species to almost every vegetated patch on the planet's surface. 'The prevalence of humans is largely attributable to their control over fire', observes Pyne, 'and the distribution and characteristics of fire have become profoundly dependent on humans (1997b: 4). As humans moved into new geographical zones with distinct fire regimes, so too did their combustive practices radiate and diversity - until most of the Earth's topography had been worked into a mosaic of adjoining, over-lapping, and mingling fire-scapes.

However, emerging in just one of these regions, a transformation in the use of fire took place, Pyne recounts, that was to be almost as consequential as the original domestication of fire. In a single combustive province - the cool, rain-soaked and densely settled western promontory of the Earth's largest landmass-a small human cohort began to renounce the application of fire to surrounding phytomass (Pyne, 2001: 168-9). 
As with the other social transformations we are addressing, the turn against fire in early modern Europe is best seen as an indissoluble mix of socio-cultural and geophysical processes. While the torching of forests and the burning of fallow had been a mainstay of European farming — as in agro-ecosystems elsewhere-for thousands of years, urban intellectuals began to see open fire as a manifestation of waste and disorder. Initially, in the sway of a scientific worldview centred on astronomical bodies moving in perfect cyclical orbits - and later taken up with economic notions of ascending spirals of accumulation, 'enlightened' agronomists came to conceive of free-range fire as an affront to the natural order (see Fernandez-Galiano, 2000: 37-8; Pyne, 1997a: 166-9). Convinced that constant reinvestment would increase the wealth of the soil —as it did the wealth of nations or firms - they plumped for ploughing surplus organic matter back into the humus rather than 'squandering' it in flame (Pyne, 1997a: 162-8; 2001: 145-6).

The resulting radical reduction of free-range fire turned out to be at least provisionally feasible, but largely for reasons that escaped the intellectual imaginations of the day. North-west and central Europe, Pyne points out, is fairly exceptional for its year round rainfall, for the absence of a rhythm of wet and dry periods that gives so many other regions a distinctive fire season (2001: 168). To this must be added the effects of geologically-recent glaciation on the landscape, a profound ecological disturbance that leaves much of Europe especially tolerant of the ongoing ecological upheaval that is the effect of agriculture (Flannery, 1994: 304; Pyne, 1997a: 18-20). All of which means that European ecology is peculiarly supportive of an intensity of farming that 
diminishes the niche of open-range fire — at the same time as it offers far fewer climatic inducements than most of the planet for fire to reassert itself.

In this way, Europe emerged as an anomalously fire-free zone: an evolutionary rupture in a million-year human combustive trajectory (Pyne, 2001: 168). What began as a purely provincial mutation, however, was packaged and propagated into a planetary norm. By way of Europe's geopolitical ascendance in the era of colonialism, regimes of fire prohibition that had been fashioned under exceptional and geographically specific circumstances, came to be exported to much of the rest of the world. In short, emissaries from one of the least pyrophytic regions of the planet took it upon themselves to impose strategies of fire prohibition on some the most fireprone places on Earth (Pyne, 1997a: 495).

Even in Europe there is evidence that the attenuation of fire had damaging effects on biological diversity and on the sustainability of agro-ecosystems (Pyne 1997a: 171). And would have had still more severe consequences were it not for another European deviation. Around the same time that fire suppression was advancing across the rural hinterland, the ecological and economic systems of Europe began to feel the effects of a subsidy from two new and vast energy sources. Products of the land and labour of overseas colonies together with the subterranean bounty of fossilised hydrocarbons were starting to reorganise the energetic conditions of Eurasia's western peninsula - at once displacing the work of broadcast burning and trumping it in previously unthinkable ways (Pyne, 1997c: 31; see also Mitchell, 2011: 16-17). 
Taking cues from Pyne, we suggest that the supplanting of free-range combustion that began in the European countryside helped to establish the geo-social conditions of the current global energetic predicament. As it did also for the particular framing of combustion that today predominates in popular and official responses to global climate change. In the following section, we look more closely at the complex relationship between burning increasing quantities of fossil biomass and decreasing quantities of living or recently deceased phytomass.

\section{Burning Ancient Biomass}

An implication of the discussion in the previous section is that western critical thinkers, with a few important exceptions, still participate in the 'provincialism' of European pyrophobia. Even when the accumulative logic of industrial capitalist modernity is rigorously dissected, there is a tendency to assume that biotic 'capital' should be allowed to amass indefinitely and without incendiary interference. But shortfalls in the critical imagining of terrestrial fire may express a broader occlusion. Modern western short-sightedness about combustion, we suggest, reflects a more generalised unwillingness to view human collective life in terms of its deep imbrication in geological processes: a reluctance, in particular, to conceive of these geologic processes as subtending biological possibilities. This in turn has consequences for thinking through the broader planetary contours of a widespread, if brief, reliance on fossilised hydrocarbons.

There are, however, promising signs of a new readiness to probe the geologic and geochemical dimensions of the current energy predicament. Resonating in significant 
ways with Pyne's pyrocentric account of socio-material formations, political theorist Timothy Mitchell has recently made a strong case that any understanding of the 'forms of collective life' requires us to take full account of the physical properties of the energetic resources which fuel them (2011: 18).

Mitchell argues that the contours of industrial capitalist modernity have been conditioned by several crucial (but also varied) properties of coal and oil. Firstly, the energetic intensity of fossil fuels — the fact that 'great quantities of space and time ... have been compressed into a concentrated form'-is important, for this has implication for their mechanical and thermal work-rate as well as for their ease of storage and transportability (Mitchell, 2011: 15). Secondly, it is significant for both geopolitics and capital-labour relations that the major reservoirs of utilisable hydrocarbons have a geographically uneven distribution, and that this localisation is subterranean. Thirdly, it matters to the imagining and the organising of modern social life that recoverable fossil fuels have been found in such quantities that is their very abundance that has required careful management. And finally, it is of consequence that the geological conditions that generated these fuels are effectively unrepeatable, meaning that their depletion is a singular and irreversible event (Mitchell, 2011: 12$16,39-42,243)$.

As Mitchell makes clear, these attributes have been the object of concerted sociomaterial orderings. Specific practices, institutions and imaginaries have channelled the flow of hydrocarbons in particular directions, volumes and velocities. While we cannot explore the details here, what is important to us is that Mitchell's attentiveness to the entanglement of social and energetic 'powers' builds on rather than belittles the 
significance of the physico-chemical properties and geological characteristics proper to hydrocarbon deposits. As we glimpsed earlier, 'following closely the oil itself' (Mitchell, 2011: 253) implies a journey into geologic formations and elemental compositions that vastly precede and exceed any human orchestration.

Mitchell's narrative also takes us through the transition from earlier forms of collective life energised by living phytomass, wind, water and animal muscle through to fossil-fuelled prime movers (2011: 12-15). In a parallel manner, Pyne tracks a shift from human reliance on more-or-less direct solar flow to dependence on reservoirs of fossilised hydrocarbon - anticipating Mitchell's plot in his account of how this bounty of buried sunshine exponentially increases socially-available energy (2001: 155). And, just as Mitchell demonstrates how the energetic concentration of fossil hydrocarbons is a condition of possibility of a new generation of industrial machines, Pyne stresses the importance of new fossil-fuelled engines: the metal-encased combustion chambers that contain and channel the unprecedented energetic intensity of coal and oil (2001: 135-6). When it comes to elaborating on the geophysical implications of this shift, however, we discern a subtle but significant difference in these two accounts.

What Pyne's account adds to the story of the rise of a new kind of combustion is the tale of a corresponding decline of different modes of combustion (2001: 129). In his more pyrocentric narrating, burning ancient biomass in tightly sealed compartments adds new fire to the Earth, while subtracting a much older fire. Electric or gaspowered heating substitutes for open fires, petrochemical-based herbicides, pesticides and fertilisers replace flaming fallow, and at the same time mechanised practices of 
fire fighting attempt to extinguish forest or grassland fire (1997a: 540). Under regimes of fossil fuel combustion, Pyne claims, flame is cut off from its once direct contact with air, earth and vegetation, diminishing into a tiny automated spark cloistered within powerful machines. Henceforth `(c)ombustion occurs outside the biosphere and within mechanical casings that have so divided burning into its constituent reactions that the outcome qualifies only minimally as fire' (Pyne, 2001: 128).

The cumulative effect of this increasing substitution of contained and concentrated fossil biomass combustion for broadcast burning of biomass has been a wholesale rearrangement of terrestrial fire regimes. Crucially, for Pyne, the flames that the new order of internal combustion seeks to displace and extinguish are not only those of preceding human collectives - they are the fires proper to the planet itself. Along with a burgeoning body of social scientists, both Pyne and Mitchell confront the ways in which anthropogenic burning of fossil fuels are impacting on vital earth systems on a geological scale. Yet only Pyne and a select few fire scholars have acknowledged the corresponding attenuation of another fire. And they have recognised that this extinguishing is itself a process of planetary significance, no less a geological event than the conversion of subsurface hydrocarbons into greenhouse gases.

Perhaps the key to this insight is that combustion - whatever its fuel or source of ignition - is above all a metamorphic process (Pyne, 2001: 120). Mitchell, for all his acknowledgement of more-than-human elemental properties, still conceives of energy primarily in terms of its potential for the kinetic or mechanical work that modernising socio-economic orders have increasingly demanded of it. It is Pyne, however, who 
draws us into an energy economy in which the calculable pressures, propulsions and transmissions that have come to define the work of energy in the industrial era are but a smaller part of a much more expansive range of energetic reactions. In the following two sections, at Pyne's prompting, we move beyond the restrictive focus on combustion as prime mover and engage with the long human history of tapping fire's many transmutational possibilities.

\section{Broadcast Burning}

It is not only Europe's fire suppression that began as an anomaly. 'When fossil hydrocarbons were first exhumed,' Pyne observes, ‘they were a European eccentricity' (1997a: 540). In the form of the banishment of broadcast burning and the embrace of fossil-fuelled, metal-chambered combustion, what started out as an oddity has been projected into a near-global aspiration. Moreover, Europe's head-start in activating the concentrated energies of fossil hydrocarbons provided much of the energetic drive - the fire-power - for global mobilisation. This often forceful expansion has in turn opened up new energetic domains for exploitation, not least being the subsurface hydrocarbon reserves of distant regions, as Mitchell recounts 2011: 84).

Mainstream social thought, we have been insinuating, may be better informed about the two hundred year-long diffusion of 'internal' combustion and its consequences than the achievements of the preceding million or so years of human-sparked external combustion. Akin to Mitchell's examination of the ordering practices that sprang up around the apparent superfluity of oil deposits, historians of fire have explored the 
complex dealings of our predecessors with the energetic abundance of their organic environment. From the time of its capture, they recount, fire provided warmth and light, and kept predators at bay. It helped open densely forested land to sunlight, purged ecosystems of pests and pathogens, and promoted new plant growth - in the process attracting game animals that strategic fire-lighting then helped drive and trap (Pyne, 1997a: 233; 1998: 9; 2001: 49). At some point, human fire-wielders would have recognised that periodic torching of accumulating phytomass in a forest, scrubland or savannah greatly reduced the likelihood of more intense, life-threatening wildfires (Pyne, 1997b: 303).

In appropriating the role of ignition from lightning and volcanism, fire-handling hominins began to transform the fire ecology of the Earth, rearranging fuel-loads and selecting for fire-tolerant species, and in this way accelerating an already decisive planetary feedback in favour of heightened combustability (Pyne 1994: 890). By taking over wildfire's ability to release the chemical energy bound up in living vegetation, humans began to channel the products of photosynthesis toward species they favoured — and towards themselves. At first unintentionally, but later deliberately, they harvested foodstuffs that were partially of their own creation (Goudsblom, 1992: 31; Gómez-González et al, 2011). Recently, the early role of cooking in significantly enhancing the calorific value of food has been stressed: a practice credited with increasing brain size, facilitating mobility, and a range of other hominin transformations (Wrangham, 2009).

It has been suggested that the tending of fire - the need to keep it alive at all timesplayed a pivotal role in very early forms of social organisation. 'It was simply 
impossible to keep a fire burning for long without at least some social cooperation and division of labour in order to guard it and fuel it' writes sociologist Johan Goudsblom (1992: 40). Anthropologist Richard Wrangham speculates that cooking was the impetus to social specialisation - initiating the sexual division of labour (2009: 130), while Pyne proposes early social groups were defined by shared fire (2001: 24). Contemporary fire scholars conceive of the cycle of plant growth and regrowth modulated by broadcast burning as being at the very heart of nomadism of hunter and gatherer societies (Pyne, 1997b: 303; see also Deleuze and Guattari, 1997: 383), while an older tradition — linked with Heidegger-implicates the blazing bonfire with the gathering in and settling down that inaugurates the polis (Iyer, 2002).

Fire, it may be, is so deeply bound up with human collective life that isolating and gauging its specific socio-cultural consequences is near impossible, especially over the very longue durée. Or as Bachelard concludes `Fire is .... privileged phenomenon that can explain anything' (1987: 7). But if we hew more closely to the practice of broadcast burning and to its energetic contours, a few key points can be made with more confidence. Perhaps most fundamentally, Pyne insists, human propagation of free-burning fire remains an inexact procedure, never fully disinvesting itself from the '... wild fluctuations of energy release and mass transfer' of natural fire (1982: 20). Because every fire season and each individual burn brings together its own unique combination of weather, topography, ignition and available fuel, every fire retains a vital element of experimentalism or trial and error (Pyne, 1998: 33; 2001: 15). Into this blend of contingencies we must add the accruing evidence of the speed and magnitude of climate change across the geological era in which humans were learning to work with free-range fire. Although this brings us 
back into the realms of speculation, a sense of the wild oscillation between glacial and interglacial periods throughout the Pleistocene and its likely impact on fire regimes suggests the extremely high stakes of the ongoing hominin experiment with broadcast burning (see Calvin, 2002: 3-4). And the fact that collective learning needed to begin afresh, again and again.

Pyne's other key point is that once a brand of human fire has inserted itself substantially into an ecological mix, its removal can be every bit as environmentally destructive as the careless introduction of new fire (1997b: 253, 322-7). As many folk or indigenous fire-technicians make clear, timely application of fire to a valued landscape is an act of responsibility; the withholding of flame a gross negligence (see Langton, 1998: 53; Franklin, 2006). Alongside a more dutiful disposition, there is also plentiful evidence of traditional fire users who treat burning as play and pleasure (see Jones, 1969: 226). Under the weight of the fire-suppressive regulations of the European colonial era and the modes of 'environmental management' that succeeded them, Pyne argues, countless traditional fire regimes have been disassembled, incendiary skills have been lost or compromised, pyrophytic ecosystems degraded or unravelled (2001: 57-64; see also Jones, 1969; Kull, 2002; Laris and Wardell, 2006). Biological diversity, too has suffered as multiple `species' of socio-material fire have been extinguished. And in many cases, fierce life-threatening wildfire has returned. Especially in those regions where seasonal rhythms alternatively plump the landscape with biomass and then dry it out, prohibitions on broadcast burning have played out with a vengeful logic that reads like textbook Bataille (see Pyne, 1997b: 320). 
Today, the short-lived faith in tightly-looped, fossil fuel-driven energetic cycles spiralling into endless growth curves is on the wane. While it is now widely known that this `restricted' economy is saturating the Earth's atmosphere with excess carbon, how our ancestors dealt with the build-up of carbon-rich material in their worlds remains thinly thought out. Perhaps what the social study of energy has most to glean from the deep, rich, history of broadcast burning is a sense of how current concerns with certain kinds of 'work' still reflect priorities of the modern fossil fuel age: how a prioritisation of measurable thermal and mechanical outputs shrinks the scope of what energy can be seen to do. Referring to Australia, but gesturing toward much of the inhabited planet, Pyne asserts that the skilled application of fire `allowed the Aborigine to move a continent' (1997b: 31). But this is 'movement' in a more expansive sense than usual: one in which terminus, direction, the calculus of speed and force mean little. It is energy being tapped, not to exert pressure on discrete objects or to propel individual bodies, but to metamorphose material worlds: energy construed as `a catalyst, an accelerant, a magnifier' of changes already stirring in the cosmos (Pyne, 1998: xviii). It belongs to what we might term, after Bataille (1991), an 'unrestricted' or general energetic economy.

To understand something more of this 'play' of energy in human history, we turn to a period that in many respects mediates between energetic regimes dominated by broadcast burning and by fossil fuel combustion: a multi-millennial spree of pyrotechnical experimentation which began in the countryside but burgeoned in the town. Following fire into expanding urban centres, we begin to get a sense of the role of pyrotechnology in both the aggregating and the segregating of human bodies, its contribution to the embellishing of urban material existence, and the ways in which it 
is implicated in a more general escalation of the energy intensity of human life. Or as Wertime deftly introduces his chosen terrain:

The post glacial epoch in south western Asia, particularly after about 8000 $\mathrm{BC}$, was a time of discovery and exploitation of the material worlds during which tribesmen on the flanks of the Taurus, Zagros and Alborz mountains became arbiters of biological evolution by taming animals and cultivating plants and instigators of technological revolution by learning the uses of fire and the potential uses of earth (1964: 1257).

\section{Pyrotechnology}

Whether there is a causal relationship between the beginning of settled agrarian life and the bumpy shift into an exceptionally stable interglacial period is still open to debate, as is the precise connection between resurgent post-glacial afforestation and changing patterns of anthropogenic broadcast burning. Agriculture is usually defined in terms of an intentional selection of biota and a shortening of food chains that serves to channel nutrients towards human consumers: a set of innovations that allows for more efficient food-energy production and corresponding population growth, while also binding human communities to arduous labour (Diamond, 1997: 88; De Landa, 1997: 108). Supplementing, this narrative, Pyne invites us to consider the centrality of combustion in agricultural production, reminding us of the vital role of burning phytomass for intensifying and sustaining the flow of energy through agroecosystems. 
According to Pyne, the 'fallow' which fuels agricultural flame is not simply waste or residue, it is primarily vegetation grown with the very intention of burning it (2001: 71-2). Once human collectives commit themselves to managing the quantity and quality of organic fuel on which fire feeds, he argues, their influence over the operations of a 'fire planet' steps up a vital notch. And in this sense, it might be argued, agriculture takes on a geological significance, not so much by way of the soil it churns or the species being it reshapes, but through its radical reorganisation of the conditions of terrestrial combustion.

Much has been written about agriculture's generation of an unprecedented energeticnutritional surplus, and how the management of this abundance is bound up with profound changes in the structure of social relations. However, rather less attention has been devoted to the role of the intensification of combustion in the novel diversification and stratification of social orders. To address the significance of fire in agrarian social formations draws us from the fallow-fuelled fields and into the villages and towns that housed growing numbers of sedentary human beings. Here, fire is set to a whole range of new tasks. As metallurgist J.E. Rehder explains:

The material fabrics of nearly all settled civilizations have by and large consisted of things that exist only because of pyrotechnology - the generation, control, and application of heat, which at sufficient temperatures can alter the properties and compositions of all materials (2000: 3).

Pyrotechnology scholars surmise that over the course of tens of thousands years of cooking foodstuffs, humans gradually divined the transformative effects of fire on 
other materials (Wertime 1883: 450; Pyne, 1997b: 302). Fire, they learned, hardened wood, cracked rock, baked clay. Applications of this knowledge came to play an important role in agriculture: fired clay vessels were used for carrying, storing and preparing agricultural produce, water cisterns were lined in brick and lime, metals provided hard edges for cutting through soil, wood, flesh and stone (Wertime 1973: 672; 1983: 448; Pyne 1997a: 41). Whereas agriculture involved the crucial step of cultivating biomass in order to burn it, the pivotal stages in combusting other material was the raising of the intensity of heat through successive innovations in the containment and channelling of fire that began with the permanent hearth (Rehder, 2000: 9; Wertime, 1973: 672).

Architectural theorist Luis Fernandez-Galiano speculates that built structures began as shelters for fire - and remain inseparable from processes of combustion. 'Architecture', he writes, 'regulates natural energy flows and channels the energy accumulated in combustible substances for the benefit of the living beings who inhabit it' (2000: 5). At the core of the mutual development of domesticated fire and the built environment is the hearth: the heat and light-giving focus of familial and communal life. While anthropologists and philosophers have long meditated on the symbolic function of the hearth in melding disparate bodies into a communal group, a more materialist approach suggests we also look to the role of the permanent fireplace and its fabrications in keeping bodies at a respectful distance. From out of the artisanal hearth came the bricks, tiles, plaster and cement that rendered the material infrastructure of the town durable and impervious - and thus provided barriers and divisions as well as shared spaces. In this way, the hard-baked products of ovens, kilns and furnaces played a substantive part in a new spatio-temporal distribution of 
bodies - helping regulate 'the movement of human flesh' under conditions of an unprecedented concentration of people and consociating species (see De Landa, 1997: 27-8)

Eventually, urban centres would grow into geological forces in their own right: `enormous and dense tectonic plates of humanity’ in the words of Michel Serres (1996:16). But perhaps it is the more subtle, simmering engagement with the geologic elements that are the key to the city's role in the gradual transmutation of the Earth. Again, it is the hearth that has been identified as the crux of a novel explorative attitude toward the transformation of minerals and ores. 'Its walls', Wertime ventures were a self-registering pyrometer showing in their colors and hardness the degrees of temperature attained as well as the oxidizing or reducing atmospheres' (1973: 722). Early advances in pottery - the technology most intimately related to the activity of the cooking hearth — included new modes of shaping, firing, patterning and glazing (Wertime, 1973: 676). Moreover, the neolithic pottery kiln reached temperatures at which copper and other metallic ores could be smelted (Rehder, 2000: 42).

Pyrotechnology research speculates about formative synergies between the ceramic arts and metallurgy: potters providing smiths with the techniques and fire-proof materials to make moulds and crucibles, metallurgists supplying the metals and oxides used to colour and glaze pottery (Wertime, 1964: 1265; Smith, 1981: 127-8). The fire chambers at the core of early industrial pyrotechnology were lined in brick and later, metals - materials that are themselves pyrotechnical products. As kiln and furnace technology advanced, artisans effectively climbed a ladder of rising heat intensities, from the modest $100 \mathrm{C}$ at which roasted gypsum produced plaster of paris to the 
baking of clays just above $500 \mathrm{C}$, up to $1100 \mathrm{C}$ for the smelting of copper and gold, and just beyond the $1500 \mathrm{C}$ mark for extracting iron from its ores and fusing silica into glass (Wertime, 1964, 1973). In this context, Wertime reflects, `early smiths viewed not one element at a single temperature, but the whole world of matter on an ascending scale of heat' (1964: 1264).

The gradual expansion of minerals and metallic ores that could be successfully subjected to heat-induced changes of state was partly a result of getting better performance from fuels— especially through the introduction of charcoal—and novel techniques for pumping up furnace temperatures (Wertime, 1964: 1261). But it also depended, crucially, on largely tacit understandings of the conditions produced by the varying chemical concentrations of the gas atmosphere of each firing (Wertime, 1964: 1265-6). As is the case with broadcast burning, the pyrotechnical complex is not a matter of exact science, a point stressed by Gilles Deleuze and Felix Guattari in their philosophical musings on metallurgy (1987: 405-6). Along with variable energycontent of fuels and non-standardised furnace design, it is the inevitable 'impurities' of the materials involved - many of which serve as catalysts or vital ingredientswhich ensure that each heat-induced transformation is a unique event (Smith, 1981: 54)

But even as they present themselves in aggregate and inconsistent forms, the elements of pyrotechnical activity have invariable properties: they enter into specific chemical reactions and have set thresholds for changes of state. In what is in many ways an elaboration on the patient, inter-generational acquisition of experience that makes for effective open-field burning, early industrial pyrotechnology was at once a process of 
open-ended experimentation and a disciplined engagement with the determinate physico-chemical conditions of the material world. What could be achieved and how it could be improved being a matter of trial and error, improvisation, observation, and the effective transmission of the acquired knowledge to chosen others (Rehder, 2000: 7). As Wertime sums up:

\begin{abstract}
Although they might have been launched as innocent and isolated skills, the pyrotechnic crafts in the years between 10,000 B.C. and 2000 B.C. became formidable industrial "disciplines," entailing the most severe chemical controls on daily operations (1973: 670).
\end{abstract}

Perhaps even more fundamentally, it is not just the 'how' of pyrotechnology that has been explorative and experimental, it is the 'why'. In recent decades scholars of metallurgy and related industrial arts have begun to emphasise the largely noninstrumental origins of both techniques and products. The impulse behind most pyrotechnical achievements has not been necessity, metallurgist Cyril Smith insists, but `a rich and varied sensual experience of the kind that comes directly from play with minerals, fire, and colors' (1981: 203). Across all the early crafts, he suggests, what eventually settled into formal knowledge of the properties of matter emerged from practices with purely aesthetic or 'decorative' intentions (1981: 242). As Wertime chimes in: `(i)t was through working with bright glittery metals that men came to have some scientific understanding of the physical forms of materials' (1973: 674). Reflecting more specifically on technology and product uptake in the first historical-geographical centre of artisanal pyrotechnology, anthropologist Benjamin Roberts and his colleagues also point beyond the sphere of necessity or purpose: 
Metallurgy in Eurasia originated in Southwest Asia due to the widespread adoption of, and experimentation in, pyrotechnology and the desire for new materials to serve as aesthetic visual displays of identity, whether of a social, cultural or ideological nature (Roberts et al, 2009: 1019)

To fulfil the desire for pyrotechnical experimentation and production, however, demanded an energetic calculus of a rigour beyond that required of agricultural or broadcast burning. In Ancient Greece it took 1000 mule-loads of juniper wood for the single firing of a lime kiln; to smelt a kilogram of copper in Cyprus called for 300 kilograms of charcoal (Wertime, 1983: 452; Rehder, 2000: 157). As was the case in feeding agricultural fire, groves were cultivated with the intention of supplying artisanal ovens with fuel-wood or charcoal (Smil, 2006: 86). For some theorists, this suggests that fuel requirements were met more-or-less sustainably (Rehder, 2000: 159). Others disagree, arguing that the ascending energetic appetite of protoindustrial pyrotechnology led to massive deforestation and irreversible environmental change. 'The depredations of the industrial hearth, furnace, and kiln have been primary, been committed intensively over the past four millennia, been gradualistic and inexorable, and been largely concealed' insists Wertime (1983: 445). The debate is complex and unresolved. But if it is the case that irreversible deforestation occurred then the implication is that early pyrotechnology was already effectively 'mining' carbon; not so much tapping a through-flow of solar energy as burrowing into the energy budget of a by-gone era.

The products of pyrotechnology composed the urban built environment, aesthetically enriched urban cultural life, and circulated in far-ranging trade networks (see Braudel, 2002: 60-1). Baked clay provided building materials, domestic ware and the first 
medium for writing, metals were shaped into jewellery, tools, weapons, and not least, currency - the tokens that `established the norms of weight and value and monetary trust for urban life' (Wertheim, 1973: 680). Like the effects of fire applied to vegetation, the outputs of a prodigious pyrotechnology may be too diverse, too utterly ubiquitous, to pin to specific societal impacts. But perhaps the prime incitements of the pyrotechnical-agricultural complex and its energetic adventures lie in the bigger picture - in a broadened vision of shifting human implication in the folds and flows of the geologic realm.

Just as broadcast burning began to `cook the Earth’ (Pyne, 2001:129), the application of fire to an ever-expanding range of materials can be seen as a radical intensification and extension of the human capacity for heat-induced transmutation of the geologic substance of the Earth. Whereas open fire goes to work on the planet's surface - plays across its living envelope - both agriculture and industrial pyrotechnology begin to rummage deeper. As Wertime muses on the mutually enmeshed developments that characterised the agricultural hearths of the post-glacial epoch:

the plutonic subsoil yielded the chief materials of pyrotechnology. This subsoil underlay the surface that gave man his bread. Food-producing man and pyrotechnologic man were engaged in a common revolution in these two layers of the earth (1983: 448).

Or in the words of Deleuze and Guattari: `Artisans-metallurgists ... follow the matterflow of the subsoil' (1987: 412). While agriculture took advantage of soil fertility laid down and revitalised by active geomorphological processes, pyrotechnology burgeoned in zones where geologic forces had bequeathed particularly rich veins of 
mineral and ore - at junctures `where the tectonic motor of the earth squeezes out unusual fluxes from the stressed crust' (Fortey, 2005: 258, see also Wertime, 1964: 1258). Moreover, pyrotechnology introduced heat intensities into the heart of the urban environment that, with the exception of lightning, exceeded any temperatures of nature: ancient kilns and furnaces regularly reaching well above the $1200-1300 \mathrm{C}$ that volcanologists now believe to be the maximum temperature of molten lava (Rehder, 2000: 54). Whereas anthropogenic open fire usurped the spark of lightening and volcanism, it might be said that chambered fire appropriated volcanism's power to melt and metamorphose the geochemical elements of the Earth. In essence, these urban pyrotechnological practices began to reproduce the transmutational properties of the Earth and act as a geologic force.

If the combined ascent of heat gradients and the descent into the geologic strata of the Earth inject a certain directionality to human socio-material trajectories, in another sense the prolific pyrotechnical fusion of energy and matter represents a release of non-teleological forces: an outburst whose ultimate effects - even with the benefits of hindsight, we still struggle to gauge. While the supply of energy to a legion of ovens, kilns and furnaces imposes certain logistical demands, this is a challenge which appears very much secondary to artisanal pyrotechnology's open-ended metamorphic adventure. Even in the course of its containment, according to Pyne, the essence of combustion is catalytic: 'Fire remains, above all, the great transmuter' (2001: 120). Wertime, too seems to intuit that a generalised transmutability, in itself, is the key, when he says of the metals which pyrotechnology delivers into the human domain: 'They became catalysts of social life for men even as they had been catalysts of 
energy exchanges for cells in the biological organism' (1973: 680; see also Deleuze and Guattari, 1987: 411).

\section{Past and Future Fire}

Through broadcast burning of vegetated landscapes, a flame-brandishing species greatly accelerated a firing of the Earth that had already been on the ascendant for a few hundred million years. Out of baked earth, descendants of these pyrophytic hominins fashioned containers that concentrated and intensified the combustion of biomass, to the point at which the very composition of 'earthy' minerals and ores could be transformed. Eventually the metals smelted in older chambers were used to build new chambers; 'fire engines' that were at robust enough to contain and channel the highly concentrated energy of fossilised biomass, while at the same time facilitating its exhumation from the geologic depths of the Earth. The unintended consequence of combusting ancient biomass in massive quantities has been both the depletion of deposits of fossil fuels and the transformation of the atmospheric conditions of future combustion.

What can such a brief survey of combustion's longue durée bring to understandings of the current energetic predicament—and questions of fuelling future `forms of collective life'? In various ways, what Bataille shares with 'pyrocentric' scholars like Pyne and Wertime is the sense that those energetic flows that can be contained, channelled and programmed by human agents are a pale shadow of the seething energies which power earth and life processes. By attending to combustion, we begin to get a picture of the energetic reactions - the particular and peculiar interaction of 
life, atmosphere and ignition - that characterise our planet. And a sense that, however much fire is constrained, disassembled, sublimated, it cannot be abolished from the Earth. It can only be transformed.

We are at present discovering that the brief attempt to expunge free-ranging fire and substitute it with confined and routinized modes of combustion is triggering a planetscaled cascade of climatic and ecological changes. Timothy Mitchell has helped us to understand that the turn to fossilised biomass that is part of this equation is not just a matter of increasing the quantity of energy. It is also about concentrations of energy that facilitates storage and transportability, and a chemically-distilled energetic consistency that allows for focussed, tightly-controlled and repeatable operations on the object world. Viewed in the broader context of human combustive practices, we can see how these features of fossil fuel combustion have been pressed into imaginaries in which energy use is disassociated from the particularities, inconsistencies and conglomerations characteristic of localised arrangements of matter-energy. The effect of this shift, we would suggest, has been a contraction in thinking about what energy 'does' - a diminution from its role in a generalised metamorphosing of matter toward more calculable and controllable mechanical or kinetic functions. At the same time, the collective experience of energy use has tended to shift from `hands-on’ modes of experimentality and improvisation toward a dematerialised, disembodied and abstracted consumption. Handling fuel and fire gives way to consuming oil we never touch and electricity we cannot see and rarely feel.

This sublimation of combustion, Pyne and other fire scholars insist, has been incomplete. And will be short-lived. Across much of the world, open fire continues to 
blaze, and local communities continue to burn — in fields and in furnaces. 'The great technologies that began 10,000 years ago can still be found in altered form in the bazaars and workshops of Afghanistan, Iran, Turkey, Ceylon, India, Thailand, and China', observes Wertime (1973: 682). But he was writing forty years ago. Many 'species' of fire, most of them a great many generations in the making, have vanished or are under threat — and prevailing ways of thinking about energy in the social sciences are not necessarily working in their favour.

With the depletion of accessible fossilised hydrocarbons, what remains of a social world of diverse pyrotechnical practices may become even more worthy of salvage and protection. Certainly, as global climate change redistributes fuel-loads, moisture and lightning across the planet's biomes, those heterogeneous traditions of broadcast burning that have survived the onslaughts of imperial and environmental management will be as essential as ever. Fire, Pyne warns us, `appears more profusely during times of rapid and extreme climatic change.'(1994: 890). Already there is a rediscovery under way of some very old practices of combusting biomass under oxygen-depleted conditions and applying it to the soil. A traditional means of enhancing soil fertility in tropical regions of the Amazon and West Africa, biochar production is being reappraised on account of its potential for carbon sequestration. But, the way that major biochar proposals seem to be turning wholesale to the resources of the global South as a way of offsetting Northern carbon emissions suggests a highly critical assessment is needed (Leach et al, 2012). Moreover, a rather simplistic belief that soil-based carbon sequestration on a massive global scale can simply reverse the linear curve of carbon emissions looks like an unpromising way of revaluing and supporting a world of diverse agricultural traditions of fire use. 
A full-scale reassessment of human combustion needs more than just global technological fixes. The extension of an appreciation of cultural diversity to include open-rage burning skills and pyrotechnical knowhow might be a good start, along with a reassessment of the role of collective fire use as means of locally modulating climatic and ecological variability. But an adequate theoretical understanding of fire ought to go further than this - and recognise that terrestrial fire, in all its manifestations, is and always has been a geochemical and geophysical process. If, as Pyne (1994: 880) proposes, hominins `seized at least partial control over a fundamental natural process' as soon as they begin to set fire to work on the Earth on a significant scale, then it might be argued that our species became human precisely in the course of our experiments in geologic agency. If only speculatively, such considerations suggest that social theoretic engagements with recent claims about the impact of human activity on earth systems - the Anthropocene thesis — will need to range more broadly than the last few hundred years of 'industrial' combustion. Not only might we begin to ask what kind of terrestrial agents we have already been, but also how — or from where — we acquired our capacity to use fire to transform the Earth (see Clark, 2012, Yusoff, 2013).

Just as life on Earth - give or take some significant setbacks - shows a long-term tendency towards diversification, so too has terrestrial combustion both intensified and diversified over its geological span. To acknowledge that our own species has a special role in the extrapolation of fire's possibilities entertains an unfashionable avowal of human uniqueness, much as any gesturing toward a deep temporal trend in earthly flammability dices with teleology. In a sense, however, the idea that 
humankind has recently mutated into a being with sole charge for terminating one geologic era (the Holocene) and inaugurating another (the Anthropocene) already implies at certain exceptionality, while it also leaves unattended the question of just how our home planet engendered a creature with such earth-shaking powers.

But, the Earth conceived in terms of its definitive combustability - a planet which we understand 'will burn regardless of what humans do' (Pyne 1994: 907)—is one on which the eventual emergence of a fire-wielding species, while not to be expected, should hardly be taken as a surprise. The human propensity to take hold of fire, to find ever-new applications for flame and ever-new energy sources to perpetuate it, might be seen as well within the capabilities of the solar system's most flammable celestial body. If still rather speculative, these are the kind of vistas that open up when we take into account not only the human capacity to utilise energy in different ways, but the deep energetic constitution of human and terrestrial existence; when we begin to consider not just the humanisation of geology, but the geologisation of the human. Viewed through the smoky lens of combustion, it is not only the current order, but every form of human collective life that ought to be construed as a `geo-social formation'. And when it comes to blazing trails out of the current energetic predicament, perhaps there is something to be learned from both the discipline and the 'flamboyance' that shine forth in other geo-social formations.

\section{References}

Bachelard, G. (1987) The Psychoanalysis of Fire. London: Quartet 
Bataille, G. (1991) The Accursed Share: Volume I. New York. Zone.

Bataille, G. (1993) The Accursed Share: Volumes II \& III. New York: Zone.

Blanchot, M. (1995) The Work of Fire, Stanford, CA.: Stanford University Press,

Berna, F., Goldberg, P., Horwitz, L., Brink, J., Holt, S., Bamford, M., and Chazang, M. (2012) `Microstratigraphic evidence of in situ fire in the Acheulean strata of Wonderwerk Cave, Northern Cape province, South Africa', Proceedings of the National Academy of the Sciences of the USA, online at: www.pnas.org/cgi/doi/10.1073/pnas.1117620109 : E1215-E1220

Bowman, D., Balch, J., Artaxo, P., Bond, W., Cochrane, M., D’Antonio, C., DeFries, R., Johnston, F., Keeley, J., Krawchuk, M., Kull, C., Mack, C., Moritz, M., Pyne, S., Roos, C., Scott, A., Sodhi., N and Swetnam, T. (2011) 'The human dimension of fire regimes on Earth', Journal of Biogeography, 38:, 2223-2236

Braudel, F. (2002) Memory and the Mediterranean. New York: Vintage.

Calvin, W. H. (2002) A Brain for all Seasons: Human Evolution and Abrupt Climate Change. Chicago: University of Chicago Press.

Clark, N. (2011) Inhuman Nature: Sociable Life on a Dynamic Planet, London: Sage. 
Clark, N. (2012) 'Rock, life, Fire: Speculative Geophysics and the Anthropocene', Oxford Literary Review, 34 (2): 259-276.

Crutzen, P. (2002) 'Geology of Mankind', Nature 415 (6867): 23.

De Landa, M. (1997) A Thousand Years of Nonlinear History. New York: Swerve Deleuze, G. and Guattari, F. (1987) A Thousand Plateaus: Capitalism and Schizophrenia. Minneapolis: University of Minnesota Press.

Diamond, J. (1997) Guns, Germs, Steel: The Fate of Societies. New York: W.W. Norton.

Fernández-Galiano, L (2000) Fire and Memory: On Architecture and Energy. Cambridge, MA.: MIT Press.

Flannery, T. (1992) The Future-Eaters. Sydney: Reed.

Fortey, R. (2005) The Earth: An Intimate History. London: Harper Perennial.

Franklin, A. (2006) `Burning cities: a posthumanist account of Australians and eucalypts', Environment and Planning D: Society and Space, 24 (4): 555-576.

Goldammer, J. G and Crutzen, P. J. (1993) 'Fire in the Environment: Scientific Rationale and Summary of Results of Dahlem Workshop' in J.G Goldammer and P. J. 
Crutzen (eds) Fire in the Environment: The Ecological. Atmospheric, and Climatic Importance of Vegetation Fires, Chichester: Wiley.

Gómez-Gonzáleza, S., Torres-Díaza, C., Bustos-Schindlerb, C., and Gianolic, E (2011) 'Anthropogenic fire drives the evolution of seed traits', Proceedings of the National Academy of the Sciences of the USA, 108 (46):18743-18747

Goudsblom, J (1992) Fire and Civilization. London: Allen Lane the Penguin Press.

Iyer, L. (2002) 'The City and the Stars: Politics and Alterity in Heidegger, Levinas and Blanchot', Journal for Cultural and Religious Theory 3 (3) 1-15

Jones, R. (1969) Fire-stick farming. Australian Natural History. 16 (7): 224-8.

Kull, C. (2002) `Madagascar aflame: landscape burning as peasant protest, resistance, or a resource management tool?' Political Geography 21: 927-953.

Langton, M. (1998) Burning Questions: Emerging Environmental Issues for Indigenous Peoples in Northern Australia. Darwin: Centre for Indigenous Natural and Cultural Resource Management, Northern Territory University.

Laris, P and Wardell, D, (2006) 'Good, bad or 'necessary evil'? Reinterpreting the colonial burning experiments in the savanna landscapes of West Africa', The Geographical Journal, 172(4): 271-290. 
Leach, M., Fairhead., J. and Fraser, J. (2012) 'Green grabs and biochar: Revaluing African soils and farming in the new carbon economy', Journal of Peasant Studies, 39 (2): 285-307.

Marlon, J., Bartlein, P., Carcaillet, C., Gavin, D., Harrison, S., Higuera, P., Joos, F., Power, M and Prentice, I (2008) `Climate and human influences on global biomass burning over the past two millennia', Nature Geoscience 1: 697 - 702 .

Mitchell, T. (2009) ‘Carbon Democracy’, Economy and Society 38 (3): 399-432

Mitchell, T. (2011) 'Carbon Democracy: Political Power in the Age of Oil', London: Verso.

NASA Earth Observatory (2013) Global Maps: Fire. Online at: http://earthobservatory.nasa.gov/GlobalMaps/view.php?d1=MOD14A1_M_FIRE (accessed 22/7/2013)

Pyne, S. (1982) Fire in America: A Cultural History of Wildland and Rural Fire. Princeton, NJ.: Princeton University Press.

Pyne, S (1994) Maintaining Focus: An Introduction to Anthropogenic Fire Chemosphere, 29 (5) 889-911.

Pyne, S. (1997a) Vestal Fire. Seattle and London: University of Washington Press 
Pyne, S. (1997b) World Fire: The Culture of Fire on Earth. Seattle and London: University of Washington Press.

Pyne, S. (1997c) 'Frontiers of Fire' in T. Griffiths and L. Robin (eds) Ecology and Empire: Environmental History of Settler Societies. Carlton South, Vic.: Melbourne University Press.

Pyne, S. (1998) Burning Bush: A Fire History of Australia. New York: Henry Holt.

Pyne, S. (2001) Fire: A Brief History. Seattle and London: University of Washington Press.

Pyne, S. (2004) Tending Fire: Coping with America's Wildland Fires. Washington: Island Press.

Rehder, J. E (2000) The Mastery and Uses of Fire in Antiquity, Montreal \& Kingston: McGill_Queens University Press.

Roberts, B., Thornton, C. and Pigott, V. (2009) 'The Development of Metallurgy in Eurasia', Antiquity, 83: 1012-22

Serres, M. (1995) The Natural Contract, Ann Arbor: University Of Michigan Press.

Smil, V. (2006) Energy, Oxford: Oneworld. 
Smith, C. S. (1981) A Search for Structure: Selected Essays on Science, Art, and History, Cambridge, MA.: MIT press.

Stoekl, A. (2007) Bataille's Peak: Energy, Religion, and Postsustainability.

Minneapolis: University of Minnesota Press.

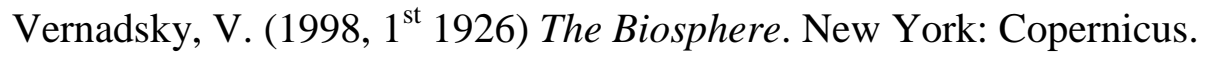

Wertime, T. (1964) 'Man's First Encounters With Metallurgy’, Science, 146 (3649) $1257-1267$.

Wertime, T. (1973) `Pyrotechnology: Man's First Industrial Uses of Fire’, American Scientist, 61 (6) 670-682.

Wertime, T. (983) 'The Furnace versus the Goat: The Pyrotechnologic Industries and Mediterranean Deforestation in Antiquity', Journal of Field Archaeology, 10 (4) 445452.

Wrangham, R (2009) Catching Fire: How Cooking Made us Human. London: Profile.

Yusoff, K. (2013) 'Geologic Life: Prehistory, Climate, Futures in the Anthropocene' Environment and Planning D: Society and Space, 31 (5) 779 - 795. 
Nigel Clark is Chair of Social Sustainability at the Lancaster Environment Centre,

Lancaster University. He is the author of Inhuman Nature: Sociable Life on a Dynamic Planet (2011) and co-editor of Material Geographies (2008) and Extending Hospitality (2009). His current research interests include the geologic politics of the Anthropocene and the relationship between capitalism and the Earth.

Kathryn Yusoff is a Senior Lecturer in the School of Geography at Queen Mary University of London. Her work focuses on political aesthetics, geophilosophy and environmental change (including climate change, extinction and the Anthropocene). She is currently working on a book about "Geologic Life" that examines the genealogies, geontologies and geographies of the Anthropocene.

\section{keywords}

energy, fire, Bataille, pyrotechnology, Anthropocene, fossil fuels

\section{Combustion and Society: A Fire-Centred History of Energy Use}

Fire is a force that links everyday human activities to some of the most powerful energetic movements of the Earth. Drawing together the energy-centred social theory of Georges Bataille, the fire-centred environmental history of Stephen Pyne, and the work of a number of 'pyrotechnology' scholars, the paper proposes that the generalised study of combustion is a key to contextualising human energetic practices 
within a broader 'economy' of terrestrial and cosmic energy flows. We examine the relatively recent turn towards fossil-fuelled 'internal combustion' in the light of a much longer human history of 'broadcast' burning of vegetation and of artisanal pyrotechnologies - the use of heat to transform diverse materials. A combustioncentred analysis, it is argued, brings human collective life into closer contact with the geochemical and geologic conditions of earthly existence, while also pointing to the significance of explorative, experimental and even playful dispositions towards energy and matter. 